\title{
Revision of the Archiloa genus complex with description of seven new Archilina species (Platyhelminthes, Proseriata) from the Mediterranean
}

\author{
Paul M. Martens' ${ }^{1}$ \& Marco C. Curini-Galletti ${ }^{2}$ \\ ${ }^{1}$ Department SBG, Research group Zoology, Limburgs Universitair Centrum, B-3590 Diepenbeek, \\ Belgium; ${ }^{2}$ Istituto di Zoologia, Università di Sassari, I-07100 Sassari, Italy
}

Keywords: Platyhelminthes, Monocelididae, karyology, taxonomy, phylogeny

\begin{abstract}
Based on morphological and karyological investigations, the genus complex Archiloa sensu Karling (1966) is revised. The group contains seven genera, two of which are here described as new: Archiloa de Beauchamp, 1910, Archilopsis Meixner, 1938, Mesoda Marcus, 1949, Monocelopsis Ax, 1951, Archilina Ax, 1959, Inaloa gen. n., and Tajikina gen. n. The genus Pistrix Marcus, 1951 is synonymized with Mesoda Marcus, 1949. Eleven species are transferred to other genera. Seven new Archilina species are described from the Mediterranean: $A$. brachycirrus, $A$. deceptoria, $A$. etrusca, $A$. palestinica, $A$. selenifera, $A$. biselenifera and $A$. caliban. Two distinct "morphs" are recognized within $A$. endostyla Ax, 1959. The genus Archilina now contains 12 species, 8 of which occur in the Mediterranean. The karyotypes of the eight Mediterranean species are known; all of them have the basic karyotype for the Monocelididae. Within the Mediterranean, some sister-group relationships among the Archilina species could be recognized. They are probably the result of independent evolutionary lines from ancestral Archilina species.
\end{abstract}

\section{Résumé}

Le complexe de genres Archiloa sensu Karling (1966) a été révisé sur une base morphologique et caryologique. Le groupe contient sept genres, dont deux nouveaux qui sont ici décrits: Archiloa de Beauchamp, 1910, Archilopsis Meixner, 1938, Mesoda Marcus, 1949, Monocelopsis Ax, 1951, Archilina Ax, 1959, Inaloa gen. n. et Tajikina gen. n. Le genre Pistrix Marcus, 1951 est mis en synonymie avec le genre Mesoda Marcus, 1949. Onze espèces sont transférées à d'autres genres. Sept nouvelles espèces d'Archilina sont décrites de la Méditerranée: $A$. brachycirrus, A. deceptoria, A. etrusca, A. palestinica, A. selenifera, A. biselenifera et $A$. caliban. Deux "morphes" distinctes sont reconnues dans l'espèce $A$. endostyla Ax, 1959. Le genre Archilina contient à présent 12 espèces, dont 8 ont été trouvées dans la
Méditerranée. Les caryotypes des huit espèces méditerranéennes sont connus; elles ont toutes le caryotype de base des Monocelididae. Il est possible de reconnaître quelques relations de groupefrère parmi les espèces d'Archilina de la Méditerranée. Celles-ci sont probablement le résultat d'événements évolutifs indépendants à partir d'espèces ancestrales d'Archilina.

\section{Introduction}

Studies on light microscopic morphology and karyology of the Monocelididae and related Proseriata taxa led to the conclusion that the Monocelididae were not monophyletic (Curini-Galletti et al., 1984). E. Martens (1984) came independently to the same conclusion, based on electron microscopic studies. This led to the removal of the genera Archimonocelis, Asilomaria, and Meidiama from the Monocelididae. Together with the new taxon Calviria these three genera were placed in the reestablished family Archimonocelididae (Martens \& Schockaert, 1988; Martens \& Curini-Galletti, 1993). As a consequence of this, the Monocelididae became a monophyletic taxon characterized by the presence of a rather compact copulatory bulb which includes the single seminal vesicle, the prostatic glands, and hard structures differentiated from the basal lamina.

From karyological investigations (at present the karyotypes of nearly 80 monocelid species are known), a karyotype for the stem-species of the Monocelididae was reconstructed, consisting of one large metacentric, one medium-sized metacentric and one small acrocentric chromosome (Curini- 
Galletti et al., 1984; Curini-Galletti et al., 1985; Curini-Galletti et al., 1989; Martens et al., 1989b). Different karyological evolutionary lines within the Monocelididae have been recognized, as well as the existence of a correlation among karyological processes and ecological evolution (Curini-Galletti et al., 1989; Curini-Galletti \& Martens, 1990). Relationships within the Monocelididae remain unclear (see Karling, 1966 and Martens, 1983). The arrangement proposed by Karling (1978), who divided the family into two subfamilies, the Minoninae, characterized by the presence of an accessory prostatoid organ, and the Monocelididae, which contain all the other genera, has been generally accepted but has never been tested cladistically.

One of the major systematic problems is presented by the Archiloa genus complex. Karling (1966), in a partial and provisional revision of the Monocelididae, synonymized the genera Archilina, Archilopsis, Monocelopsis, Mesodia, and Pistrix with the genus Archiloa and transferred the species Monocelis cirrifera Meixner, 1943 and Monocelis scalopura Marcus, 1949 to that genus. This proposal, however, has not been generally accepted (cf. Sopott, 1972; Martens et al., 1989a). We have revised this group, studying all existing type material and living specimens of all the known European species, some of which have not been reported since their original description. In this paper we deal with the general systematics of this group and provide a revision of the genus Archilina, including descriptions of seven new species from the Mediterranean. Revisions of the other genera of the complex have been published (genus Archilopsis: Martens et al., 1989a) or are in preparation. For the delimitation of the genera and for their phylogenetic relationships, see the discussion below and the study of Martens \& Curini-Galletti (in press).

\section{Material and methods}

Specimens were collected by the authors from sandy habitats in intertidal to subtidal areas. Extraction, preservation, and histological techniques routinely adopted for Proseriata were used (see P. Martens, 1984 and Martens et al., 1989a).

The karyotype was determined from lactic-acetic orcein stained spermatogonial mitoses, as described by Curini-Galletti et al., 1989. Relative lengths (r.l. = length of chromosome $\times$ $100 /$ total length of haploid genome) and centromeric indices (c.i. = length of short arm $\times 100 /$ length of entire chromosome) were obtained from measurements of camera lucida drawings of 5-10 metaphase plates for each species. Idiograms (Fig. 12) are based on karyometrical data presented in the karyotype formula: haploid genome absolute length in $\mu \mathrm{m}$, fundamental number, relative length and centromeric index of each chromosome; chromosome nomenclature between parentheses $(m=$ metacentric; $\mathbf{s m}=$ sumetacentric; $\mathbf{s t}=$ subtelocentric; $\mathbf{t}=$ acrocentric). The fundamental number is derived according to Matthey (1949) and chromosome nomenclature follows Levan et al. (1964).

Abbreviations used for locations of the material examined are as follows: $\mathrm{ZC}-\mathrm{LUC}=$ Zoological Collection of the Limburgs Universitair Centrum; RNHM-S = Swedish Museum of Natural History.

b : bursa
co : copulatory organ
dp : diaphragm
en : intestine
fd : female duct
fg : female glands
fp : female pore
gg $_{1}:$ rhabdoid glands
gg $_{2}:$ "Kittdrüsen”
mp: male pore
od : oviduct
ov : ovary
pg : prostate glands
ph : pharynx
vde: seminal duct
sta : statocyst
t : testes
v : vagina
vi : vitellary
vp : vaginal pore
vs : seminal vesicle

Abbreviations used in the figures

\section{General systematis of the Archiloa complex}

Many of the species within the Archiloa genus complex show characters which are widely distributed within the family and can be considered as plesiomorphic (see the discussion and Martens \& CuriniGalletti, in press). These characters are: epidermis with insunk nuclei; rhabdites and rhabdoid glands present; pharynx in second half of body; ovaries in 


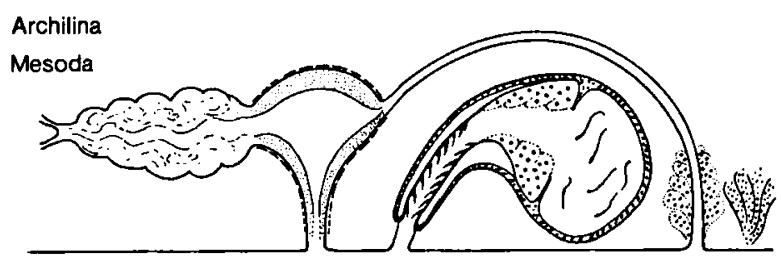

Monocelopsis
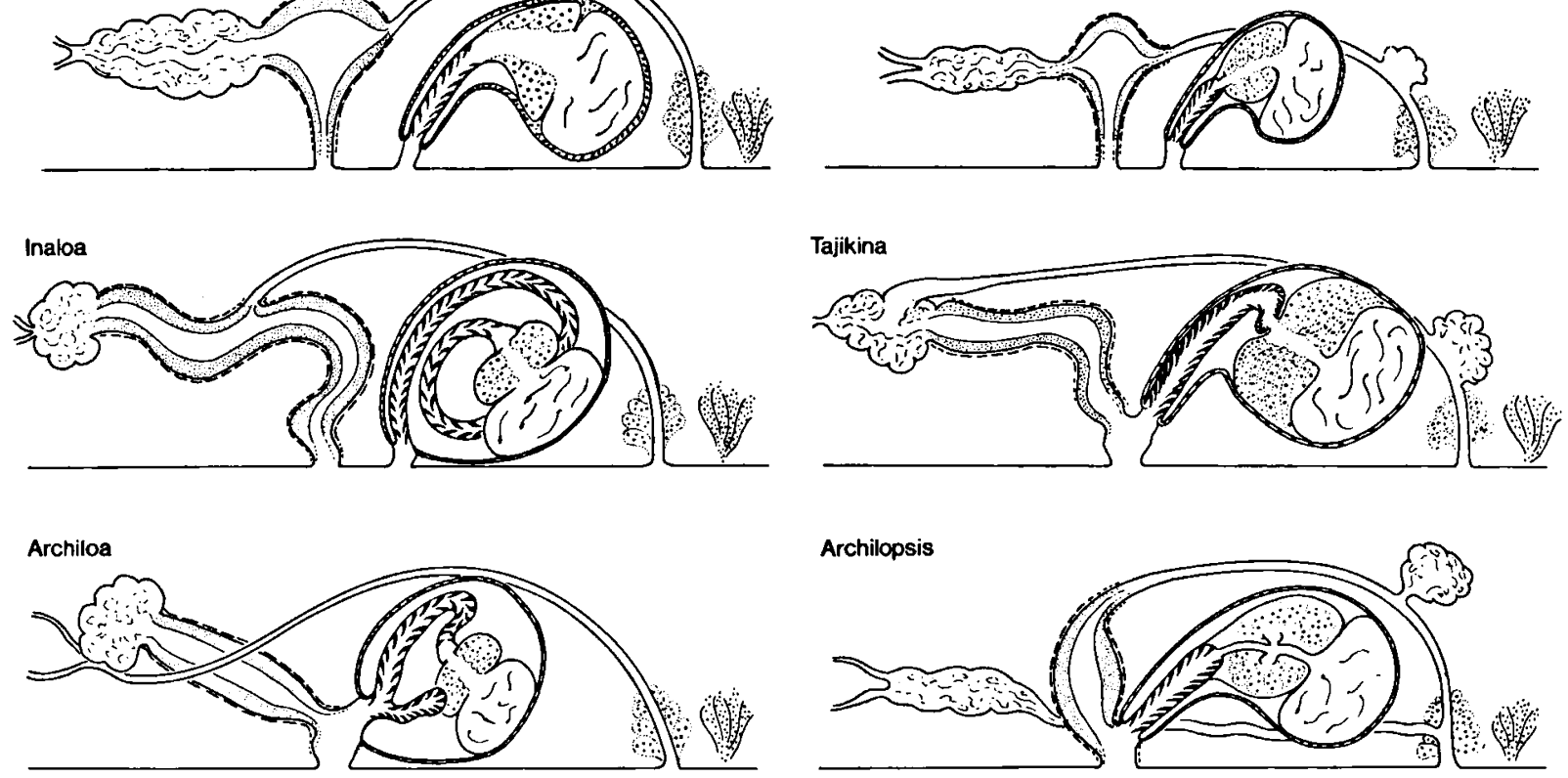

Fig. 1. Schematical reconstruction of the genital organs for the genera of the Archiloa genus complex.

front of pharynx; oviducts fused behind pharynx into common female duct; three genital pores; prepenial, rather short external vagina present; this vagina being connected with a prepenial bursa which is a part of the female duct; postpenial genito-intestinal connection (postpenial bursa) present; copulatory organ of the duplex type, with a straight cirrus and some prostatoid glands at the base of the cirrus; glands surrounding the female pore (female glands) present; glands present behind the female pore $\left(\mathrm{gg}_{2}\right.$ or "Kittdrüsen"-complex); three chromosomes present in the haploid set: one large metacentric, one medium metacentric, and one small heterobrachial acrocentric chromosome.

Within this Archiloa genus complex we recognize the following genera and species. The generic diagnoses may be compared with the above-mentioned plesiomorphic characteristics of the group (see also Fig. 1).

\section{Mesoda Marcus, 1949}

Syn. - Pistrix Marcus, 1951.

Diagnosis. - Epidermis with intraepithelial nuclei, postpenial bursa can be absent.
Type species: Mesoda gabriellae Marcus, 1949. Other species: Mesoda thelura (Marcus, 1951) n. comb. (syn. Pistrix thelura Marcus, 1951).

Tajikina n. gen.

Diagnosis. - Long vagina interna; two chromosomes in the haploid set (the karyotype is only known from the type species).

Type species: Tajikina juliae (Tajika, 1982) n. comb. (syn. Archiloa juliae Tajika, 1982).

Other species: Tajikina tajikai (Ax \& Armonies, 1990) n. comb. (syn. Archiloa tajikai Ax \& Armonies, 1990).

\section{Inaloa n. gen.}

Diagnosis. - Long vagina externa; extremely long cirrus; with a clear spherical prostatic vesicle which is separated by a muscular diaphragm from the seminal vesicle; both vesicles are more or less isolated from the bulb wall. Karyotype with four chromosomes in the haploid set (the karyotype is known from the type species and a yet undescribed species). 
Type species: Inaloa cirrifera (Meixner, 1943) n. comb. (syn. Monocelis cirrifera Meixner, 1943).

Other species: Inaloa scalopura (Marcus, 1949) n. comb. (syn. Monocelis scalopura Marcus, 1949).

Archiloa De Beauchamp, 1910

Diagnosis. - Vagina interna; absence of direct connection of the female duct with the prepenial bursa; an accessory cirrus is present; with a clear spherical prostatic vesicle which is separated from the seminal vesicle by a muscular diaphragm, both vesicles being more or less isolated from the bulb wall. Basic karyotype of the genus with four chromosomes in the haploid set (known for the three species).

Type species: Archiloa rivularis De Beauchamp, 1910.

Other species: Archiloa westbladi Ax, 1954, and Archiloa petiti Ax, 1956.

Archiloa wilsoni Stirewalt, Kepner \& Ferguson, 1940 belongs to the genus Promonotus on the basis of the absence of both a vagina and a prepenial bursa, and because the cirrus shows similarities with the cirrus of the other Promonotus species (own observations).

\section{Monocelopsis Ax, 1951}

Diagnosis. - Small species with an otoplanoid habitus; with only four pairs of vitelline follicles, only one of which lies in front of the pharynx. The nuclei of the epidermis can be intraepithelial. With five chromosomes in the haploid set and a nearly symmetrical karyotype (known for both species).

Type species: Monocelopsis otoplanoides Ax, 1951.

Other species: Monocelopsis septentrionalis (Sopott, 1972) n. comb. (syn. Mesoda septentrionalis Sopott, 1972).

\section{Archilopsis Meixner, 1938}

Diagnosis. - Vagina interna postpenially connected with the female duct; prostatic glands discharge into the ejaculatory duct via two prostatic ducts. A stylet can be present within the cirrus. Basically with five heterobrachial chromosomes in the haploid set.

Type species: Archilopsis unipunctata (Fabricius, 1826).

Other species: Archilopsis spinosa (Jensen, 1878), Archilopsis arenaria Martens et al., 1989, and Archilopsis marifuga Martens et al., 1989.

(For synonymy of the species of the genus Archilopsis, see Martens et al., 1989. To this list we add Archilopsis inopinata Martens et al., 1989, nomen nudum in Ax \& Armonies 1987, as a synonym of $A$. spinosa.)

\section{Archilina Ax, 1959}

This genus may be non-monophyletic and includes all other species of the group.

Diagnosis. - With the plesiomorphic characters as mentioned for the group. A stylet within the cirrus can be present; the postpenial bursa can be absent. Some small modifications in the morphology of the vagina and the prepenial bursa can be present.

Type species: Archilina endostyla Ax, 1959.

Other species: see below.

In comparison with Karling (1966), the system proposed here gives more attention to the morphology of the bursa, vagina, and the male bulb. Fig. 1 schematically shows the characters of the different genera (see also the discussion).

\section{Systematic account of the genus Archilina Ax, 1959}

Because of great similarities between the species within this genus, characters which are plesiomorphic for the genus (see above) will not be repeated in the species descriptions.

Archilina endostyla Ax, 1959

(Figs. 2, 12, 13B)

Syn. - Archiloa endostyla (Ax, 1959) in Karling (1966). 
Table I. Comparison of different populations of $A$. endostyla. Sizes are in $\mu \mathrm{m} ;\left(^{*}\right)$ : taken in the middle of the stylet.

\begin{tabular}{|c|c|c|c|c|c|c|}
\hline Locality & $\begin{array}{c}\text { Bosporus } \\
(\mathrm{Ax}, 1959)\end{array}$ & $\begin{array}{l}\text { Punta Marina } \\
\text { (Adriatic) }\end{array}$ & $\begin{array}{l}\text { S. Tuscany } \\
\text { (Tyrrhenian) }\end{array}$ & $\begin{array}{c}\text { Giglio I. } \\
\text { (Tyrrhenian) }\end{array}$ & $\begin{array}{c}\text { Corfu } \\
\text { (Greece) }\end{array}$ & Israel \\
\hline specimens studied & $?$ & 2 & 5 & 2 & 5 & 5 \\
\hline salinity & brackish & brackish & brackish & brackish & brackish & marine \\
\hline length of stylet & 60 & $56-58$ & $50-56$ & $50-56$ & $68-78$ & $30-39$ \\
\hline width of stylet $\left(^{*}\right)$ & $?$ & $12-16$ & $14-16$ & $12-14$ & $14-19$ & $16-20$ \\
\hline length of proximal spines & $8-12$ & $7-10$ & $7-10$ & $8-10$ & $9-11$ & $3-6.5$ \\
\hline length of distal spines & $2-3$ & $2.5-3.5$ & $2-3$ & $2-3$ & $2.5-3.5$ & $1-2$ \\
\hline
\end{tabular}

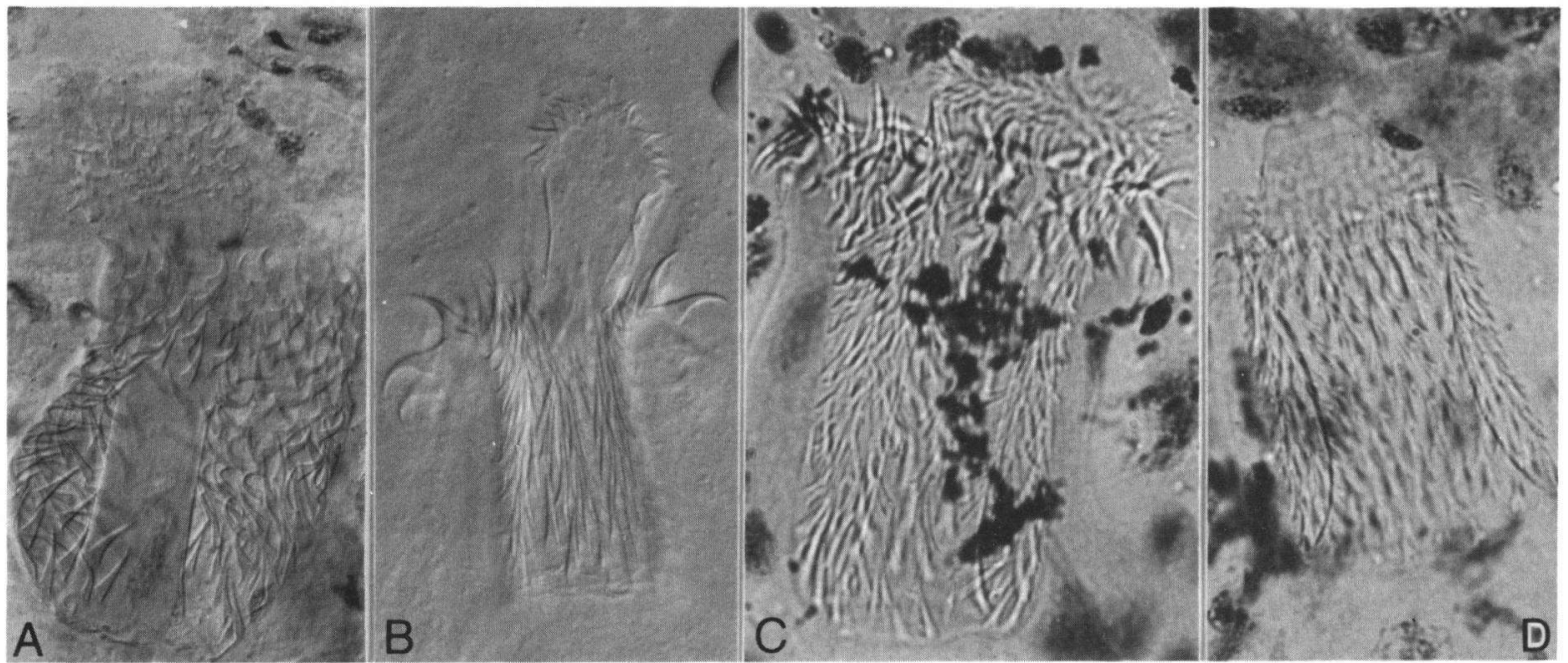

Fig. 2. Cirrus with stylet of Archilina endostyla from different populations: A, Follonica; B, Giglio Island; C, Punta Marina, D, Israel.

Distribution and material. - Turkey, Bosporus, Baltalima, 40$50 \mathrm{~cm}$ deep in coarse sand (type locality) $(\mathrm{Ax}, 1959)$. This species has a wide distribution around the Mediterranean, in medium to coarse sand from the lower intertidal to the uppermost subtidal: France, Banyuls-sur-mer (Ax, 1959); Italy, Tyrrhenian sea: Follonica (November 1984); Giglio Is. (June 1989); Punta Ala (April 1990); Adriatic sea: Punta Marina (June 1990). Greece: Corfu Is. (February 1992). Israel: Atlit (April 1988, April 1992). Type material as well as living animals of all new localities have been studied.

Description. - Our observations on the topography of the genital organs are in agreement with Ax's description (1959). We can add some details on the morphology of the cirrus and the stylet. The stylet is comparable with that of other Monocelididae. It consists of a part of the ductus ejaculatorius which is everted within the cirrus. On the outer side of this everted duct the epithelium is absent, and the basal lamina is thickened, producing a hard tube-like structure. The inner epithelium of this part is provided with cell necks of the prostatic glands. The most distal end of this everted part is not provided with a thick basal lamina, but with numerous small spines. At the base of the stylet the basal lamina becomes thinner and is continuous with that of the cirrus. By eversion of the complete cirrus, this internal stylet becomes the most distal part of the copulatory organ, and forms a functional stylet.

Some differences have been observed among different populations as far as lengths of cirrus spines, small spines, and stylet are concerned (see Table I). The biometrical data of the brackish-water populations are within the same size range; the stylet is about 3 to 4 times longer than broad. On the contrary, the only marine population examined is remarkable for the shape of the stylet (see Fig. 2D), 
which is shorter (only two times longer than broad), and for the smaller size of both the distal and the proximal spines of the cirrus (Table I). These morphological differences, together with the difference in habitat, suggest that two distinct species may exist. However, because more detailed anatomical information is lacking, we provisionally consider the population from Israel as $A$. endostyla.

The karyotype is basic for the Monocelididae (see Curini-Galletti et al., 1989 for karyometrical data of the S. Tuscany (Follonica) population). The karyotype formula for the Adriatic population (Punta Marina) is: 9.9; 5; I: 44.77, 45.42 (m); II: 34.02, $45.99(\mathrm{~m})$; III: $18.28,10.04(\mathrm{t})$; for the Israelian population: 6.4 ; 5; I: $44.77,45.24$ (m); II: $34.02,45.99$ (m); III: $21.29,13.19$ (st). The differences among populations are not significant.

Archilina subtilis (Karling, Mack-Fira \& Dörjes, 1972) comb. $n$.

Syn. - Archiloa subtilis Karling, Mack-Fira \& Dörjes, 1972.

Distribution and material. - Hawaii, Oahu, Bay of Kaneohe: Sand Island, coarse shell-sand below the low-water line, April 1969 (type locality); Coconut Island, fine sand below the lowwater line. Three whole mounts (one of them is the holotype) and two animals sectioned serially (RNHM-S) (type material has been studied).

Description. - See the original description of Karling et al. (1972).

Archilina papillosa (Ax \& Ax, 1977) comb. $\mathrm{n}$.

Syn. - Archiloa papillosa Ax \& Ax, 1977.

Distribution and material. - Galapagos, Santa Cruz, Bay of Academy, coral sand below the low-water line, September 1972 (type locality). Type material does not exist (Ax \& Ax, 1977).

Description. - The description of Ax \& Ax (1977) is incomplete, as they did not report anything of the structure of the female organs. However, they argued that this species belongs to the Archiloa group (sensu Karling, 1966). The absence of observations on the female genital organs probably implies that these organs are very simple. Therefore, we have transferred provisionally this species to the genus Archilina.

\section{Archilina vanderlandi (Martens \& Curini-Galletti, 1989) comb. $n$.}

Syn. - Archiloa vanderlandi Martens \& Curini-Galletti, 1989.

Distribution and material. - Indonesia, South Sulawesi, Sankarang Archipel, Kudingareng Keke, fine coral sand, around the low-water line, October 1984 (type locality). Two animals studied alive, one preserved as whole mount (holotype) and one serially sectioned (ZC-LUC No. 110).

Description. - See the original description of Martens \& Curini-Galletti (1989). The genital organs of this species show the plesiomorphic characters diagnostic for the genus Archilina and therefore it has been transferred to this genus (see discussion below).

Archilina duplaculeata (Ax \& Armonies, 1990) comb. $n$.

Syn. - Archiloa duplaculeata Ax \& Armonies, 1990.

Distribution and material. - Alaska, Seward, Lowell Point, coarse sand and gravel with effluent fresh water, August 1988 (type locality). Two animals studied alive, and one animal sectioned (holotype).

Description. - See the original description of Ax \& Armonies (1990). This species is characterized by two kinds of spines, which cannot be properly understood, only one kind belonging to the cirrus. The organization of the genital organs may be simple (plesiomorphic) but clear information is lacking. Thus, we provisionally place this species in the genus Archilina.

Archilina brachycirrus sp. $n$.

(Figs. 3A-E, 4, 10F-G, 12)

Distribution and material. - Corsica, Bay of Calvi, Occelluccia, $10 \mathrm{~m}$ deep in sand, September 1983 (type locality). This species 


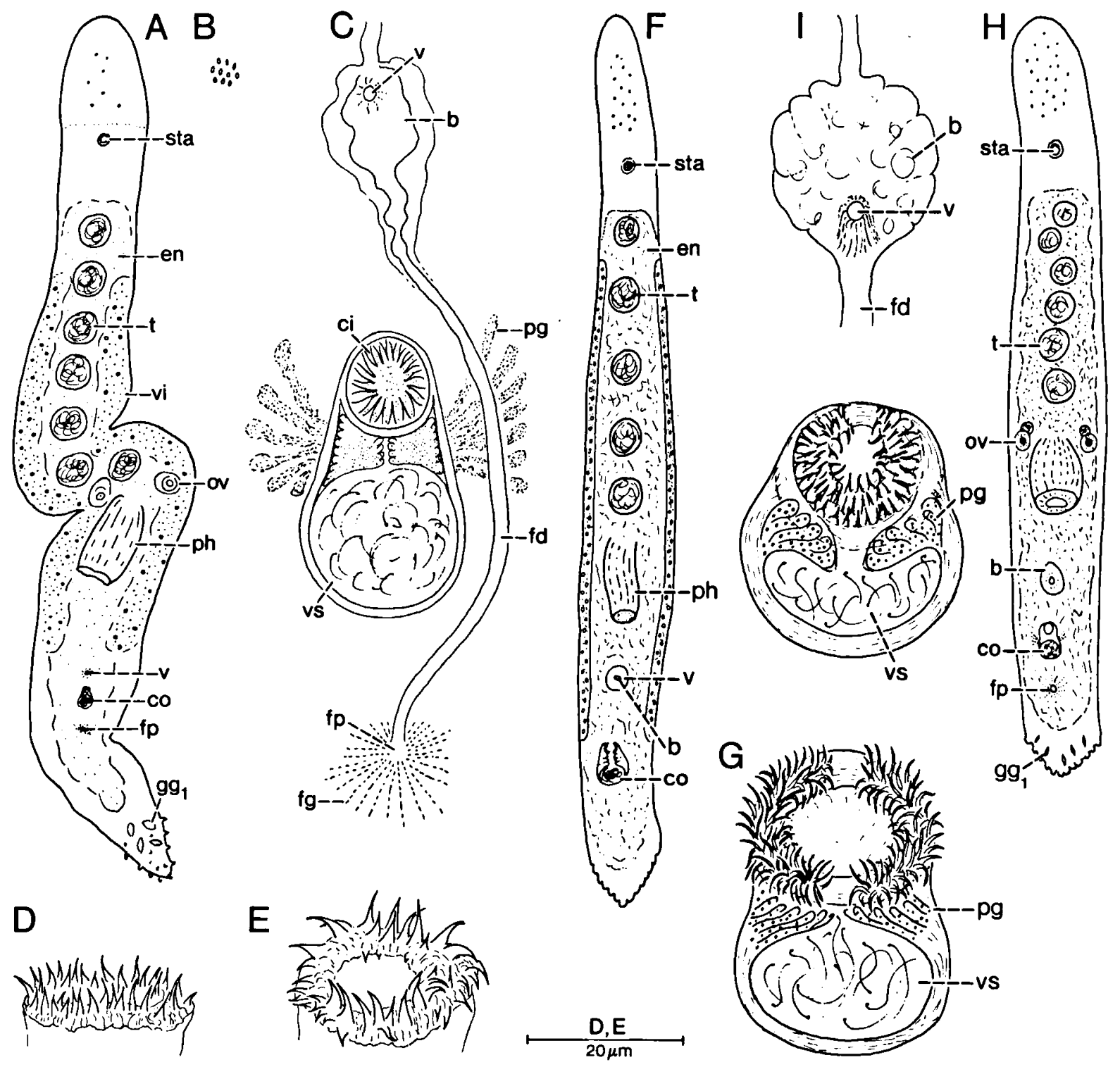

Fig. 3. A-E, Archilina brachycirrus sp. n.: A, general organization of a live animal; B, rhabdites; C, general organization of the copula tory organ from live animals; D-E, partly everted cirrus in well-squeezed animal.

F-G, Archilina selenifera sp. n.: F, general organization of a live animal; G, copulatory bulb.

H-I, Archilina biselenifera sp. n.: H, general organization of a live animal; I, organization of the bursa and the copulatory bulb.

has been found also in different sublittoral stations in the bay of Calvi between 9 and $35 \mathrm{~m}$. Several animals were studied alive; three of them were preserved as whole mounts (one of them chosen as holotype, ZC-LUC No. 178, and one serially sectioned). Three specimens were studied karyologically.

Etymology. - The name refers to the short cirrus (from the Greek brachys, meaning short).
Description. - Animal about $0.7 \mathrm{~mm}$ long. The anterior tip is rather short and has some oily drops; the posterior tip is provided with some adhesive papillae and few big rhabdoid glands $\left(\mathrm{gg}_{1}\right)$. The whole epithelium of the body contains very small oval to spherical rhabdites, which are organized in rows. The general structure and topo- 


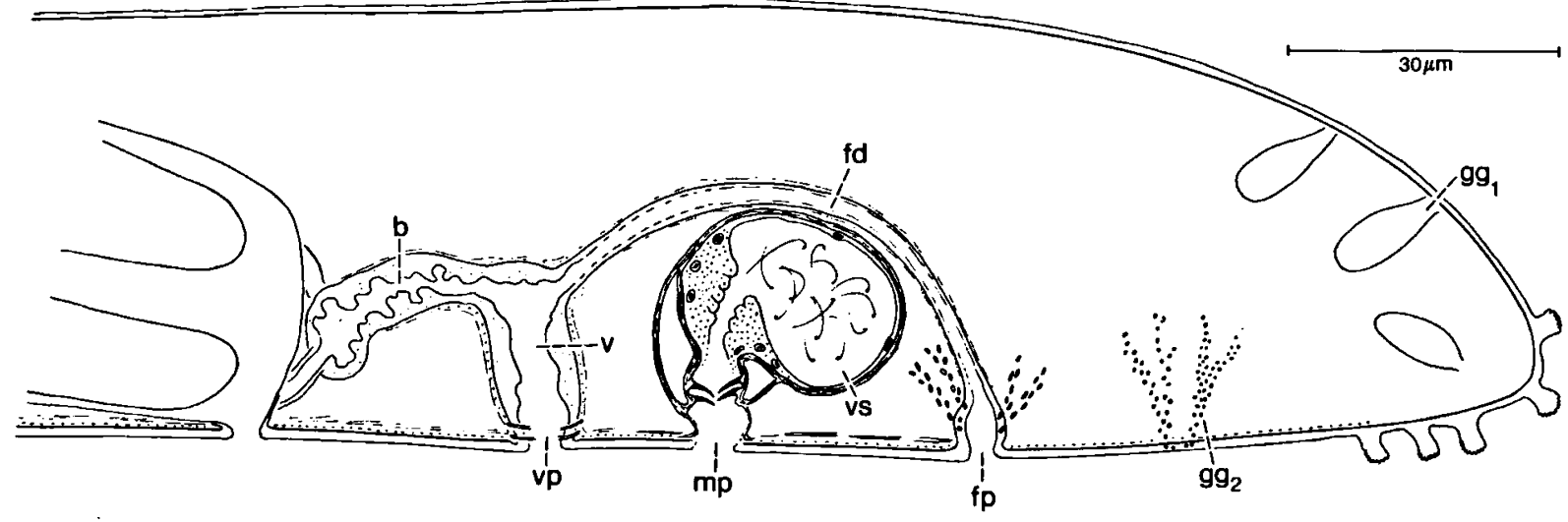

Fig. 4. Archilina brachycirrus sp. n., reconstruction of the genital organs from transversal sections.

graphy of the organs is as depicted in Fig. 3A.

Male genital organs: 5 to 8 testes in front of the pharynx; the copulatory bulb is about 50 to $60 \mu \mathrm{m}$ long and has well-developed prostatic glands. The cirrus is short, and contains only two girdles of clearly visible spines, whose tips are more or less alternating (some more very small spines may be present). There are in total about 40-45 spines, varying in length from 3 to $6 \mu \mathrm{m}$.

Female genital organs: the vitellaria run from the level of the second testis to the vagina; the oviducts fuse behind the pharynx; the female duct has an epithelium of the resorbiens type in front of the vagina. The prepenial vagina is short and broad, and forms a vaginal bursa (Fig. 4).

The karyotype is basic (formula: $8.6 ; 5 ; \mathrm{I}: 45.05$, 45.16 (m); II: 33.75, 38.47 (m); III: 21.21, $10.94(\mathrm{t})$ ).

\section{Archilina selenifera sp. $\mathbf{n}$.}

(Figs. 3F-G, 10H, 12, 13C)

Distribution and material. - Crete, Francokastelo, about $30 \mathrm{~cm}$ deep in sand, April 1990 (type locality). Six animals studied alive; four of them used for karyology; two preserved as whole mounts (one of them chosen as holotype) (ZC-LUC No. 179).

Etymology. - The name refers to the cirrus which is shaped like a half-moon (from the Greek selene $=$ moon and the Latin ferre $=$ to bring).

Description. - Small animal, about $1.5 \mathrm{~mm}$. Anterior tip provided with numerous oily drops, posterior tip with adhesive papillae and rhabdoid glands $\left(g_{1}\right)$. The general structure and topography of the organs is as depicted in Fig. 3F.

Male genital organs: about 6 to 8 testes lie medially in front of the pharynx. The copulatory organ consists of a rather compact bulb ( $60 \mu \mathrm{m}$ long). The cirrus is short and contains seven girdles of spines, varying in length from $5-6 \mu \mathrm{m}$ to about $12-14 \mu \mathrm{m}$. The girdles do not form complete circles but are interrupted at the ventral side, where the spines are absent. The cirrus is thus provided with spines in $4 / 5$ th of its cross section. Near the gap the spines are slender, with small bases, while towards the opposite side the spines progressively acquire a broader base. There is also a differentiation among the girdles, with the innermost rows having slightly hooked spines.

Female genital organ: vitellaria were not observed. Anterior to the penis, part of the female duct and a vagina could be observed; in front of the vagina the duct forms a bursa of the resorbiens type.

The karyotype is basic (formula: 10.0; $5 ; \mathrm{I}: 44.49$, 46.64 (m); II: $36.06,39.17$ (m); III: $19.24,13.95$ (st)).

\section{Archilina biselenifera sp. $\mathbf{n}$.}

(Figs. 3H-I, 10B-C, 12)

Distribution and material. - Italy, S. Tuscany, Punta Ala, about $1 \mathrm{~m}$ deep in mixed sediment in sand pockets among rocks and clusters of Posidonia, May 1990 and April 1993 (type local- 
ity). Six specimens studied alive; four used for karyology, two preserved as whole mounts (one of them chosen as the holotype) (ZC-LUC No. 180); Meloria shoals, off Livorno, October 1991, about $12 \mathrm{~m}$ deep in mixed sediment among Posidonia, one specimen.

Etymology. - The name is coined after the previous species, and refers to the peculiar cirrus, shaped as a double half-moon.

Description. - In general morphology and topography of organs, this species closely resembles $A$. selenifera, but it is smaller, being less than $1 \mathrm{~mm}$ in length. Anterior tip provided with numerous oily drops, posterior part with adhesive papillae. The general morphology and topography of the organs is as depicted in Fig. $3 \mathrm{H}$.

Male genital organ: 5 to 6 testes are present in one median row in front of the pharynx. The copulatory organ is rather compact, very similar in structure to that of $\boldsymbol{A}$. selenifera, with 6 to 7 girdles of spines which are interrupted dorsally and ventrally. In squashed animals the cirrus, lying in one plane, seems thus to be constituted by two half moons. The spines are more or less of the same shape, about 4 to $6 \mu \mathrm{m}$ long.

Female genital organs: vitellaria are very narrow and run from the level of the second testis to the copulatory bulb. An ovoid bursa, which opens to the outside through a broad vagina, is present halfway between the pharynx and the copulatory organ.

The karyotype is basic (formula: $6.7 ; 5 ; \mathrm{I}: 49.62$, 47.16(m); II: 35.33, $46.90(\mathrm{~m})$; III: 18.64, $11.72(\mathrm{t})$ ).

Archilina etrusca sp. $n$.

(Figs. 5A-F, 6, 8D-F, 12)

Syn. - Archilina sp. 1 in Curini-Galletti et al., 1989.

Distribution and material. - Italy, Elba, Portoferraio, loc. "La Salina", about $20 \mathrm{~cm}$ deep in sand with mud, in brackish conditions, April 1984 (type locality). Several animals studied alive, four of them used for karyology, two whole mounts (one of them chosen as holotype, ZC-LUC No. 181) and two animals serially sectioned (one of them chosen as paratype, ZC-LUC No. 182). Giglio Is., Giglio Porto, inside the harbour, about $20 \mathrm{~cm}$ deep in medium sand with mud (June 1989), several specimens.
Corsica, harbour of Calvi, lower intertidal in coarse sand (February 1991), three specimens.

Etymology. - The name refers to the type locality, which was an important mining station during Etruscan times.

Description. - Large animal, about 4 to $5 \mathrm{~mm}$ in length. Due to gut content the animal appears brown with the exception of the anterior tip. The epidermis is provided with small rhabdites. The tail is provided with adhesive glands and large rhabdoid glands $\left(\mathrm{gg}_{1}\right)$. The pharynx is about $250 \mu \mathrm{m}$ long. The general structure and topography of the organs can be seen in Fig. 5A and D.

Male genital organ: numerous testes ( 55 to 75 ) lie medioventrally in front of the pharynx. The copulatory organ is about $120-150 \mu \mathrm{m}$ long. Within the copulatory organ the seminal vesicle and prostatic glands are not clearly separated from each other; the prostatic epithelium forms a mass protruding medioventrally into the seminal vesicle. Dorsal to this mass the bulb is prolonged into a well-developed ductus ejaculatorius, which can be divided in three parts. The first part is about 25 to $30 \mu \mathrm{m}$ long and contains the cell necks of the prostatic glands. The second part is about $10 \mu \mathrm{m}$ long and extrudes into the cirrus (penis papilla); this penis papilla has no thickening of the basement lamina and does not form a stylet within the cirrus. The third part constitutes a cirrus which is about $60 \mu \mathrm{m}$ long. The cirrus spines are of variable length. The distalmost spines are very small and impossible to detect in living animals; they are followed immediately by a group of very long spines (up to $22 \mu \mathrm{m}$ in length). The latter are present in the upper part of the uneverted cirrus (Fig. 5F). In the proximal part of the cirrus the spines become smaller again, measuring 6-9 $\mu \mathrm{m}$ in length.

Female genital organs: The dorsolateral vitellaria extend to just behind the pharynx. The non-ciliated oviducts fuse behind the pharynx into the common female duct. From there to the vagina the duct forms a muscular bursa which has an epithelium with insunk nuclei. In the first part this epithelium is ciliated; near the vagina the epithelium is secretory (vaginal bursa). The vaginal bursa opens to the 

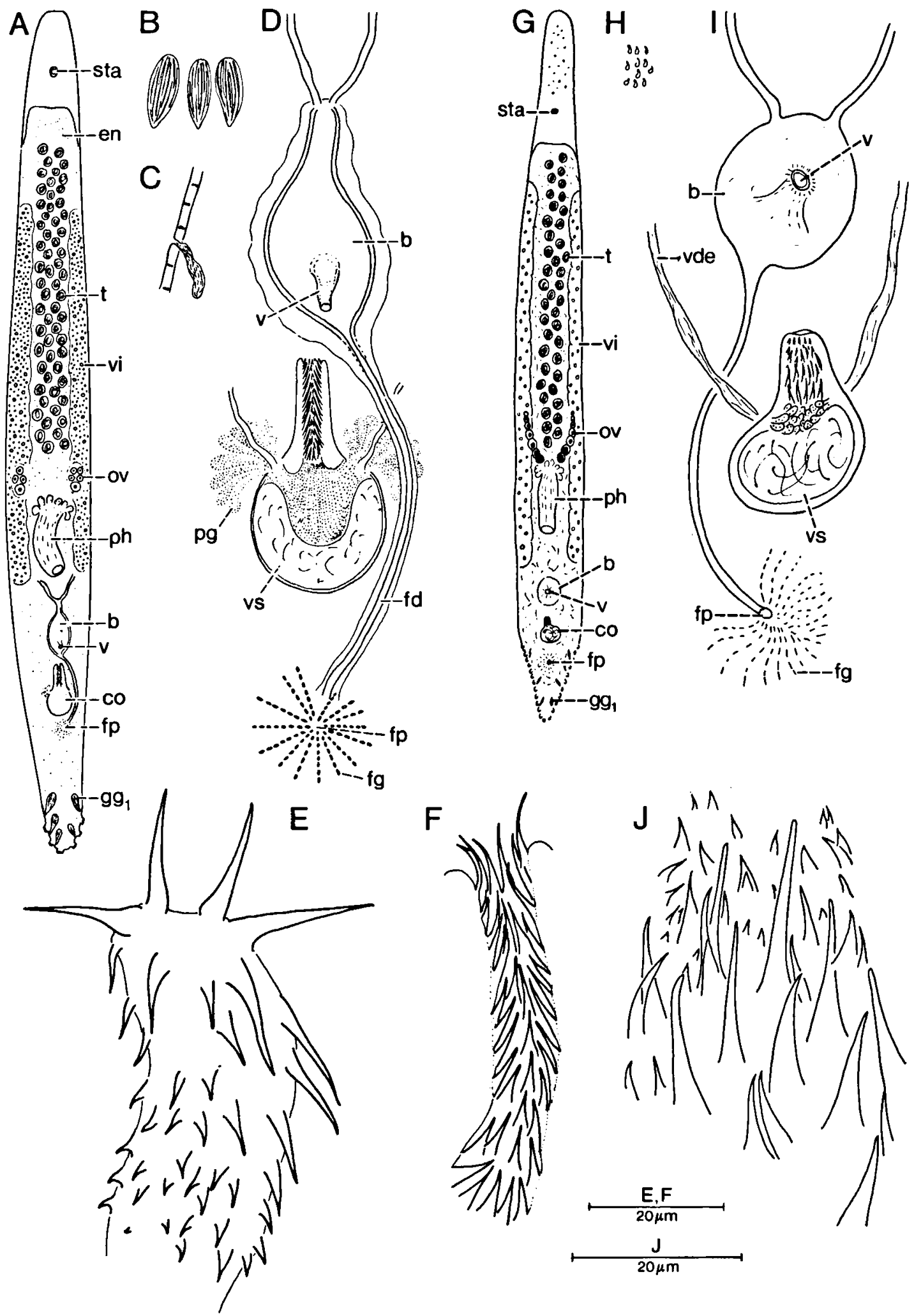


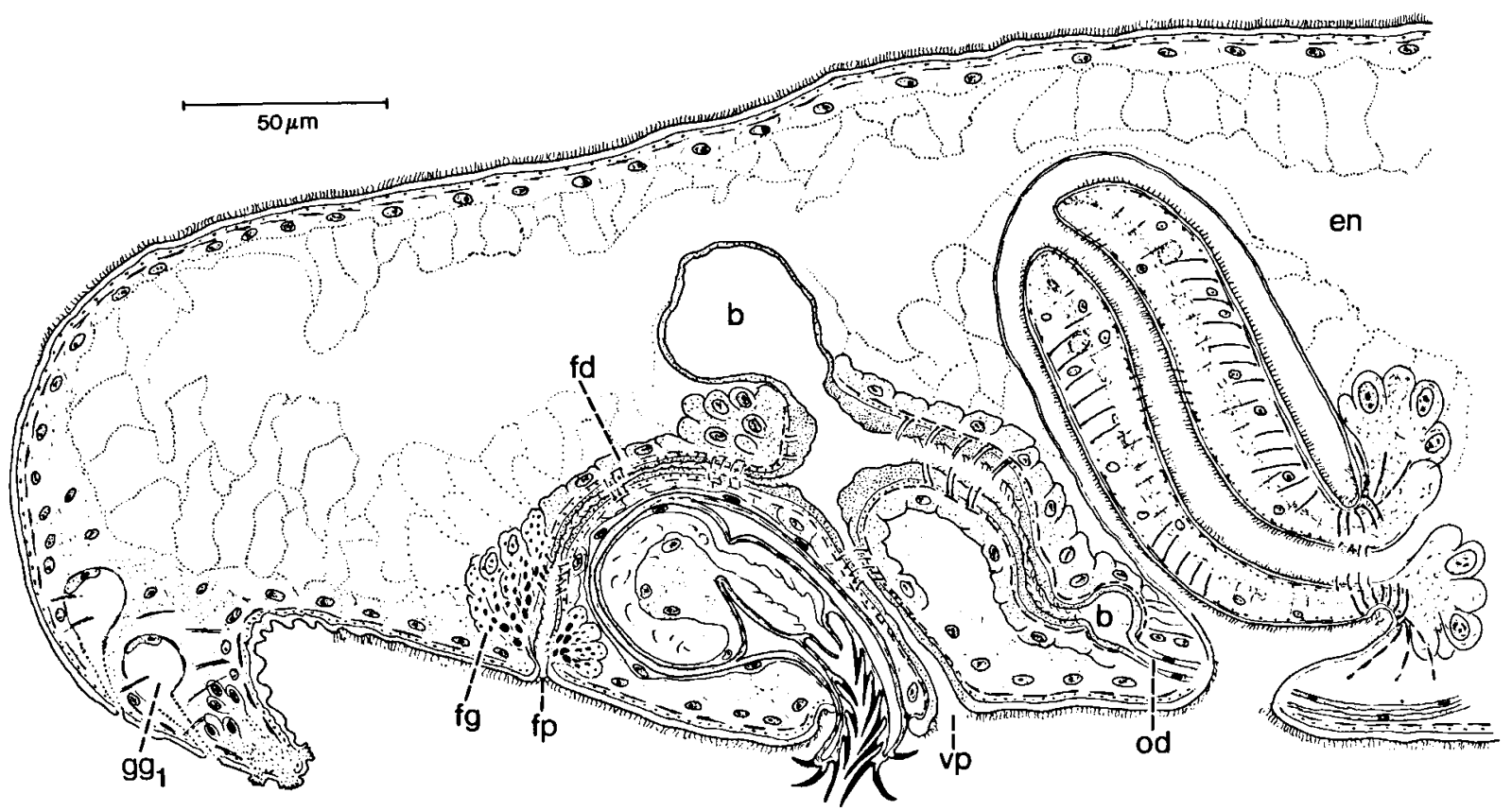

Fig. 6. Archilina etrusca sp. n., reconstruction of the genital organs from transversal sections.

outside through a muscular vagina. Dorsal from the vaginal bursa a diverticulum protrudes into the intestine. This diverticulum has a very thin wall which is not covered by gastrodermis. We did not observe either a direct connection with the lumen of the gut or an epithelium of the resorbiens type. A "Kittdrüsen" complex was not observed (Fig. 6).

The karyotype is basic (formula: $8.1 ; 5 ; \mathrm{I}: 46.76$, 45.29 (m); II: 35.74, 44.61 (m); III: 17.36, 16.09 (st) for the Elba population; 7.2; 5; I: 45.51, $46.76(\mathrm{~m})$; II: $36.14,43.03$ (m); III: $18.45,12.72$ (st) for the Giglio population; 7.6; 5; I: 46.94, 45.21 (m); II: $35.14,44.70$ (m); III: 17.92, 13.02 (st) for the Calvi population). For more information about the Elba population see Archilina sp. 1 in Curini-Galletti et al., 1989.
Archilina palestinica sp. $\mathrm{n}$.

(Figs. 5G-J, 10A, 12, 13A)

Distribution and material. - Mediterranean coast of Israel, Atlit, about $20 \mathrm{~cm}$ deep in medium to fine sand, April 1988, April 1992 (type locality). Several animals studied alive, five of them used for karyology, two whole mounts (one of them chosen as holotype, ZC-LUC No. 183).

Etymology. - The name refers to the type locality.

Description. - Large animals, about $3 \mathrm{~mm}$ long. Anterior tip provided with some oily drops. Posterior tip provided with numerous small adhesive glands and some larger rhabdoid glands. All over the body the epithelium bears extremely small, comma-like rhabdites. For the general organization and topography of the organs see Fig. 5G and I.

Fig. 5. A-F, Archilina etrusca sp. n.: A, general organization of a live animal; B, rhabdoid glands ( $\left.\mathrm{gg}_{1}\right)$ of the tail; C, epidermis of a live animal; D, general organization of the copulatory organ from live animals; E-F, partly everted cirrus in well-squeezed animal: E, distal everted part; F, proximal not everted part.

G-J, Archilina palestinica sp. n.: G, general organization of a live animal; $\mathrm{H}$, rhabdites; I, general organization of the copulatory organ from live animals; $J$, cirrus in well-squeezed animal. 
Male genital organs: About 25 to 45 testes lie in two more or less regular rows in front of the pharynx. The copulatory organ is about $100 \mu \mathrm{m}$ long. The vasa deferentia enter the copulatory bulb at the level of the prostatic glands. The cirrus is about 50 to $60 \mu \mathrm{m}$ long and 25 to $30 \mu \mathrm{m}$ broad in squeezed animals. The cirrus is straight and is provided with 8-10 irregular rows of spines. The spines at the base are long, the longest reaching a length of 16 to $22 \mu \mathrm{m}$, but these are not the most proximal ones (see Fig. 5J); closer to the tip the spines become much smaller and vary in length from 3 to $6 \mu \mathrm{m}$.

Female genital organs: the vitellaria run from behind the first testes to halfway between the pharynx and the vagina. The two oviducts fuse into the female duct at the point where an ovoid-spherical vaginal bursa is formed, which is connected to the outside by a short muscular vagina. The bursa is about 80 to $100 \mu \mathrm{m}$ in diameter. From the vaginal bursa the common female duct runs over the copulatory organ to the female pore. A bursa of the resorbiens type was not observed.

The karyotype is basic (formula: 7.8; 5 ; I: 44.84, 47.35 (m); II: $35.33,46.90$ (m); III: $18.64,11.72$ (t)).

Archilina deceptoria sp. $\mathrm{n}$.

(Figs. 7, 8A-C, 12)

Distribution and material. - France, Corsica, Bay of Calvi, in front of STARESO, 3-5 m, medium sand, 7.04 .83 (type locality). Three animals serially sectioned (one of them chosen as holotype) (ZC-LUC No. 184) and two whole mounts. Numerous other subtidal localities exist in the Bay of Calvi, in sediments ranging from fine to coarse. Banyuls-sur-mer, $6 \mathrm{~m}$ deep in coarse sediment, October 1987. Italy, Quercianella, $3 \mathrm{~m}$ deep, coarse sand, March 1986; Capraia, 10-15 m deep in medium sand, January, March 1992; Capo Caccia (Sardinia), $5 \mathrm{~m}$ deep in medium sand, March 1993; S. Margherita Ligure, $10 \mathrm{~m}$ deep in medium sand, November 1991.

Etymology. - The name refers to the fact that early observations suggested the presence of a stylet in this species (from the Latin deceptorius = misleading).

Description. - Animals about $2 \mathrm{~mm}$ long. The anterior part of the body contains some oily drops, adhesive papillae, and rhabdoid glands $\left(\mathrm{gg}_{1}\right)$. For topography and general organization of the organs, see Fig. 7B.

Male genital organs: $20-50$ testes are situated in front of the pharynx. The copulatory organ is about $90 \mu \mathrm{m}$ long. The seminal vesicle and the prostatic glands are more or less separated from each other by a poorly developed muscular diaphragm. The cirrus is about $30 \mu \mathrm{m}$ long and in living animals it seems provided with a stylet; however, when the cirrus is everted or in strongly squashed whole mounts it is clear that it actually consists of four very large, somehow gut-shaped spines which overlap each other and together resemble a stylet, 27 to $30 \mu \mathrm{m}$ long. The remaining spines are 7 to $9 \mu \mathrm{m}$ long at the base of the cirrus and towards the top of the cirrus they gradually decrease to 1 to $2 \mu \mathrm{m}$ (Fig. 8B-C).

Female genital organs: The two oviducts fuse behind the pharynx into the female duct. In some animals sperm was observed within the oviducts. The common female duct is provided with an unciliated epithelium with intraepithelial nuclei. Prevaginally, the epithelium is strongly developed and of the resorbiens type. The vagina is short, muscular, and provided with some glands. Dorsal to the vagina the female duct is provided with a strong muscular bursa with secretory epithelium. This bursa is elongated dorsally and at its proximal end it is prolonged into a non-muscular bursa of the resorbiens type which is connected with the gastrodermis. From the vaginal bursa the common female duct runs over the copulatory organ to the female pore. Behind the female pore $\mathrm{gg}_{2}$ glands are present.

The karyotype is basic (formula: 11.9; 5 ; I: 45.72,

Fig. 7. Archilina deceptoria sp. n.: A, habitus; B, general organization of a live animal; C, general organization of the copulatory organs from live animals; D-G, cirrus: D, not everted; E-F, partly everted; G, completely everted; $H$, reconstruction of the genital organs from transversal sections. 


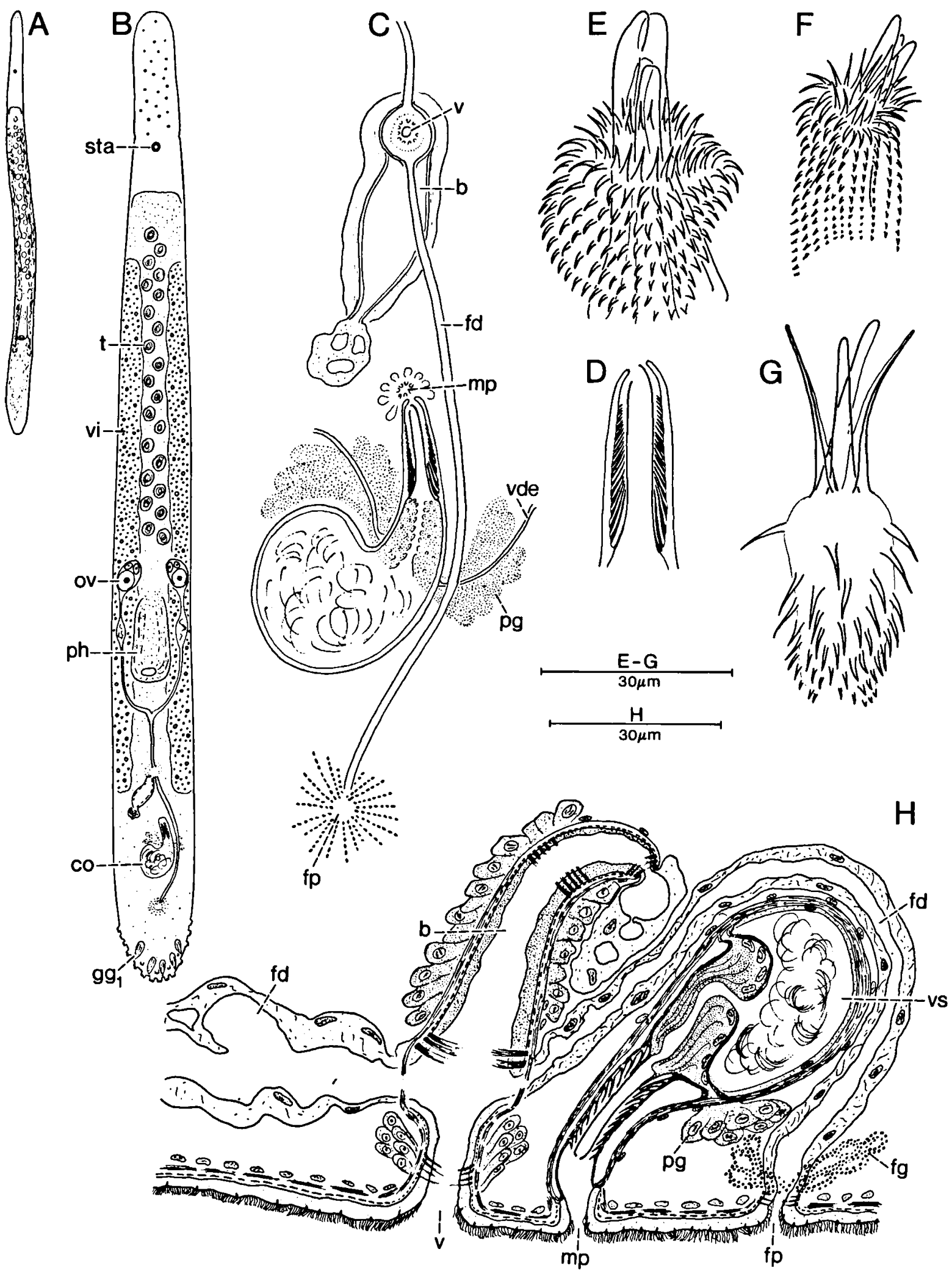




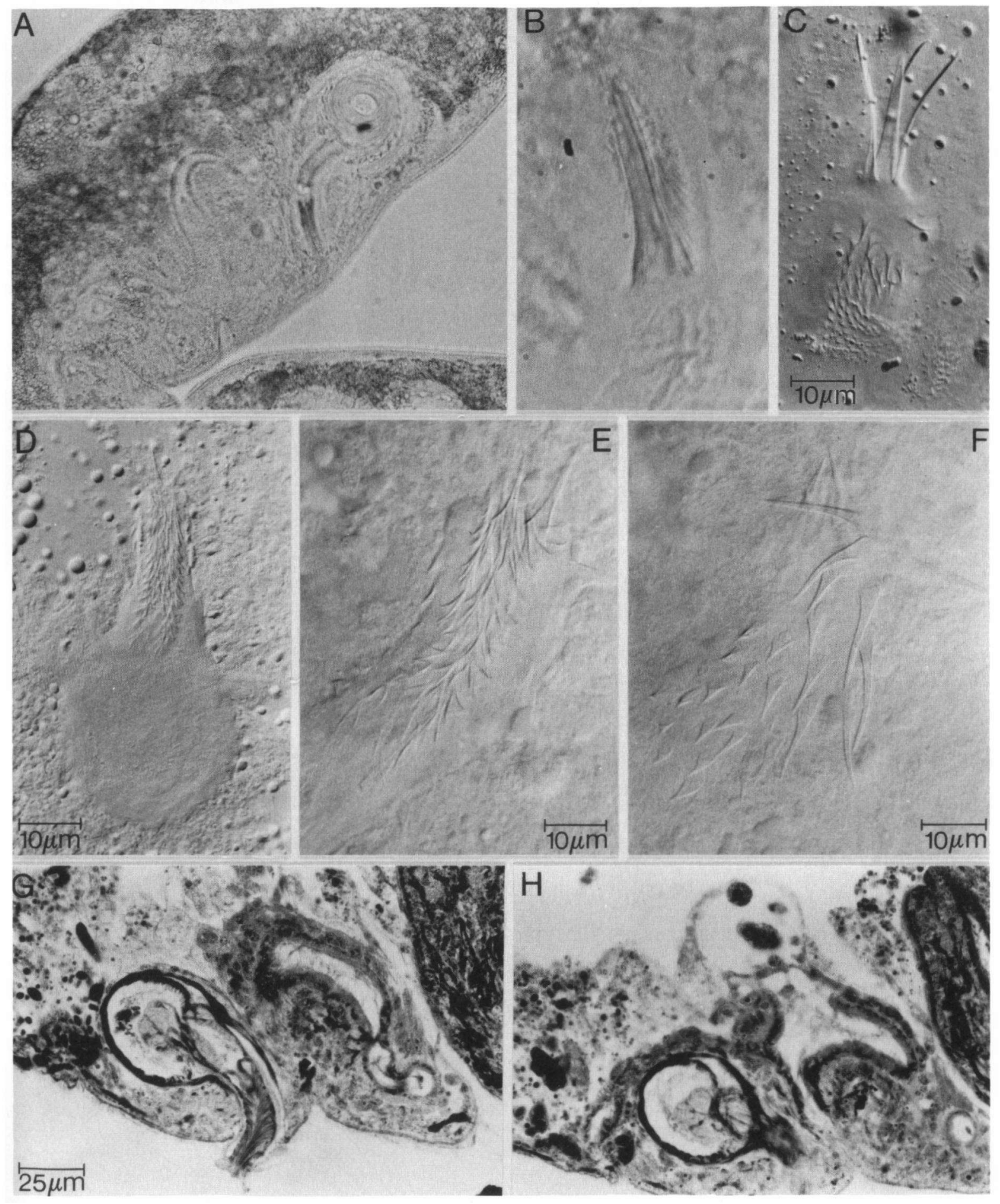

Fig. 8. A-C, Archilina deceptoria sp. n.: A, copulatory organs; B, not everted cirrus; C, everted cirrus.

D-H, Archilina etrusca sp. n.: D, copulatory bulb; E, proximal part, not everted; F, distal everted part; G-H, serial section of copulatory organ. 

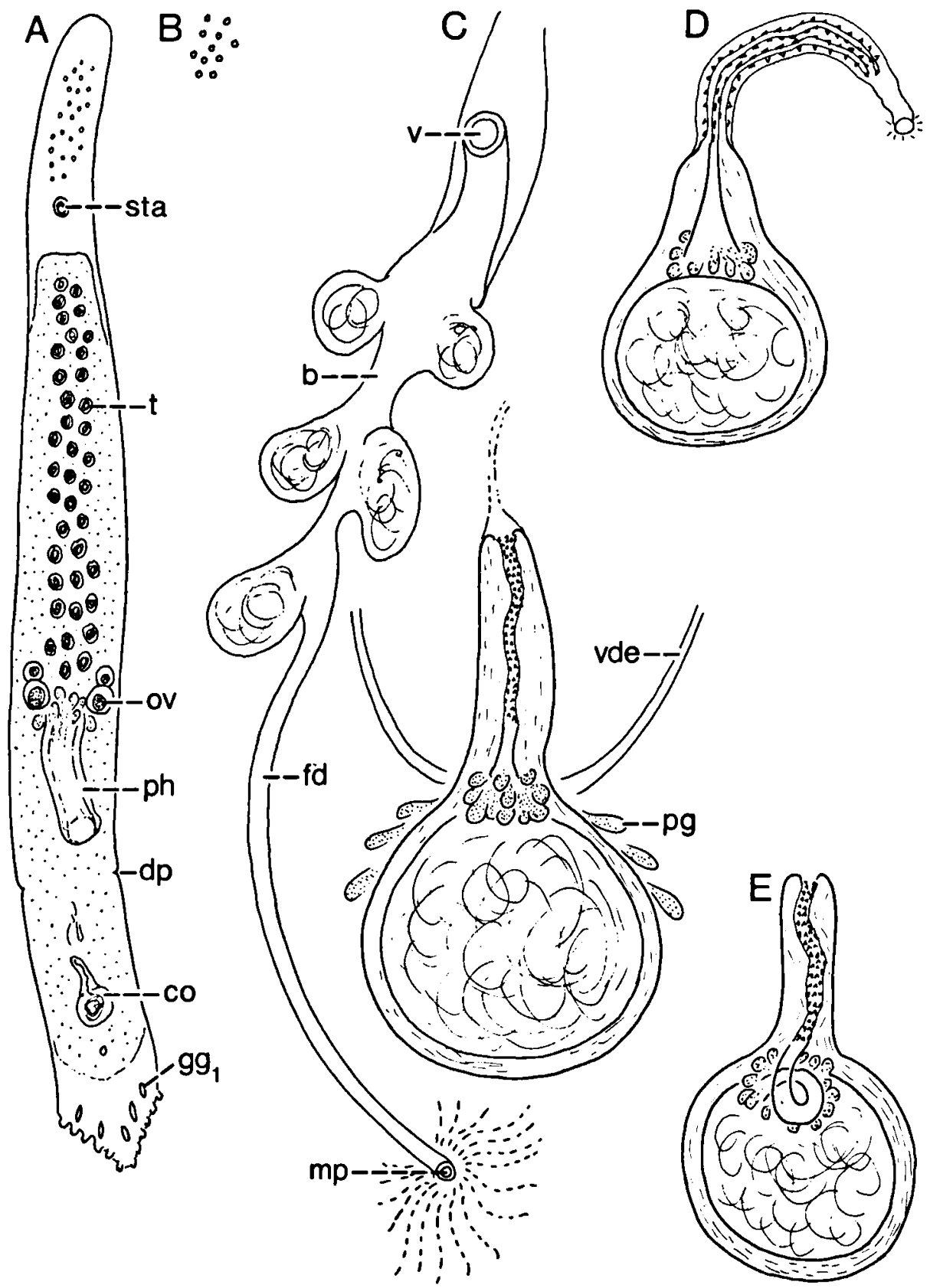

Fig. 9. Archilina caliban sp. n.: A, general organization of a live animal; B, rhabdites; C, general organization of the copulatory organs from live animals; D-E, copulatory bulbus in squeezed animals: D, everted cirrus; $E$, non-everted cirrus.

46.23 (m); II: $36.34,42.22$ (m); III: $17.95,4.77$ (t) for the Calvi population; $9.6 ; 5 ; \mathrm{I}: 45.94,47.25(\mathrm{~m})$; II: $36.53,41.84(\mathrm{~m})$; III: $17.68,10.62(\mathrm{t})$ for the Quercianella population).

\section{Archilina caliban sp. $\mathrm{n}$.}

(Figs. 9, 10D-E, 12, 13D)

Distribution and material. - Italy, Pantelleria, harbour of Scauri, about $4 \mathrm{~m}$ deep in fine sand, May 1991 (type locality). 

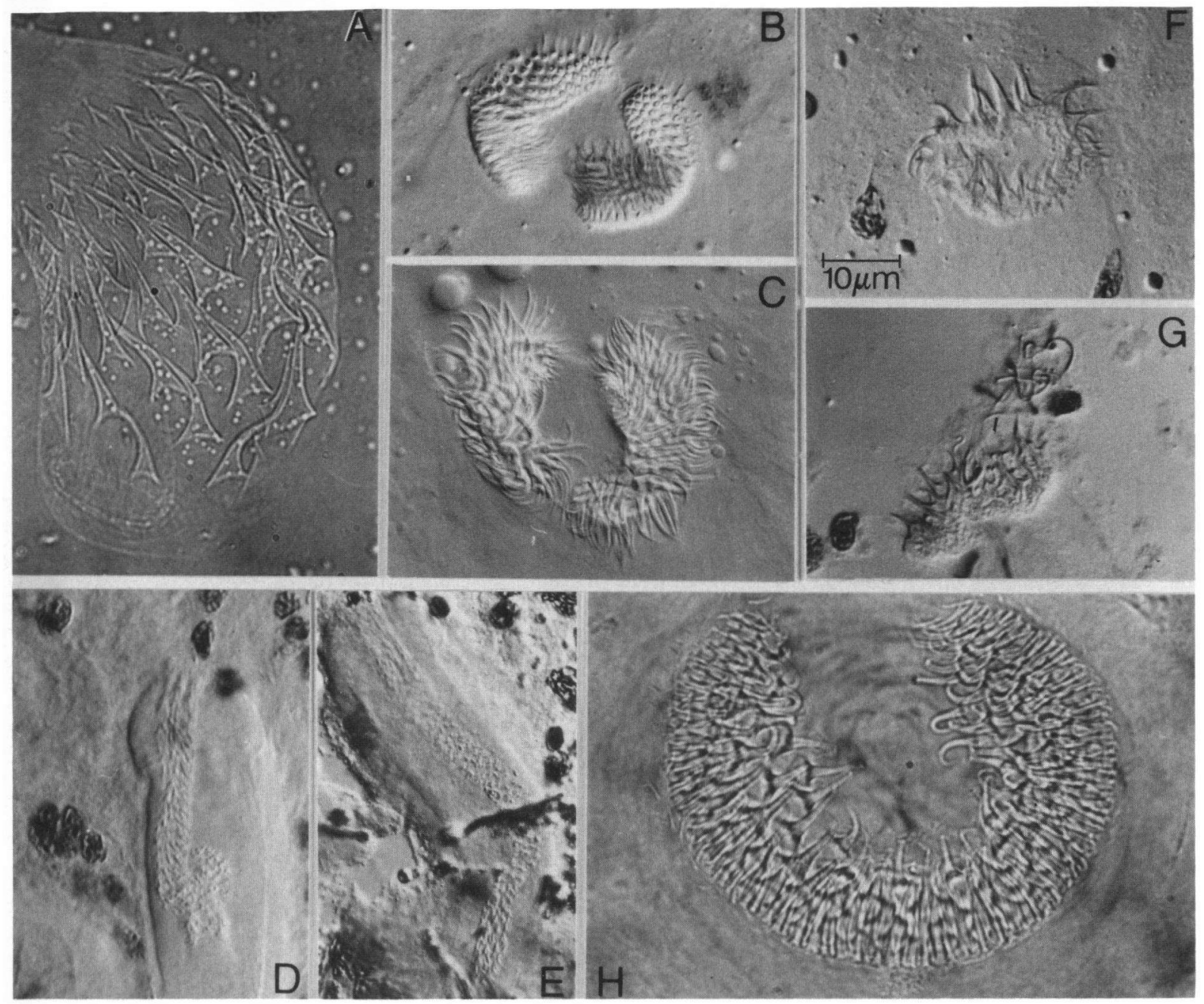

Fig. 10. Hard structures of the copulatory organs of Archilina palestinica (A), A. biselenifera (B-C), A. caliban (D-E), A. brachycirrus $(\mathrm{F}-\mathrm{G})$, and $A$. selenifera $(\mathrm{H})$.

Several animals studied alive, four of them used for karyology, and two whole mounts (one of them chosen as holotype, ZCLUC No. 185). Mediterranean coast of Israel, Shiqmona, $6 \mathrm{~m}$ deep in medium sand among rocks, April 1988; several specimens.

Etymology. - Named after a character in Shakespeare's The Tempest, set in Pantelleria.

Description. - Animals about $3 \mathrm{~mm}$ long. Anterior tip provided with some oily drops; posterior tip markedly triangular in shape, with numerous small adhesive papillae and a few large rhabdoid glands $\left(\mathrm{gg}_{1}\right)$. Small dot-like rhabdites are present in all epidermal cells. Behind the pharynx a muscular diaphragm was observed in some specimens. For general organization and topography of the organs, see Fig. 9A.

Male genital organs: About 40 testes arranged in two irregular rows in front of the pharynx. The copulatory organ consists of a spherical bulb, about $40 \mu \mathrm{m}$ in diameter, which is nearly completely occupied by the seminal vesicle. The bulb abruptly narrows into a rather long cirrus which is about $60 \mu \mathrm{m}$ long when completely inverted. At the base of the cirrus only a few prostatic glands are present. The cirrus is very mobile and variable in shape (see 
Fig. 9C-E). The proximalmost part of the strongly muscular cirrus is devoid of spines; this part can be coiled and is 15 to $20 \mu \mathrm{m}$ long. The remaining part of the cirrus is weakly muscular and here the ductus ejaculatorius forms a small channel which is provided with spines which are about $0.5-1 \mu \mathrm{m}$ long. The shape of this part of the cirrus is very variable, from nearly straight to sinuous. The male atrium is long and only visible when the cirrus is everted (Fig. 9D). During our observations the everted cirrus never came out of the animal.

Female genital organs: Vitellaria were not observed. The oviducts fuse behind the pharynx into the common female duct. From behind the vagina to the level of the copulatory organ (and in some specimens even farther) the female duct widens into a large bursa of the resorbiens type containing many serially arranged lateral bulges. The anterior part of the bursa is connected with the outside through a small, short vagina.

The karyotype is basic (formula: 9.0; 5 ; I: 47.66, 46.41 (m); II: 34.48, 42.96 (m); III: 17.51, 8.01 (t) for the Pantelleria population; 9.3; 5; I: 46.07, 46.56 (m); II: 36.33, 42.06 (m); III: 17.59, 8.32 (t) for the Israelian population).

\section{Discussion}

At the time of Karling's revision (1966), the genera Pistrix, Mesoda, Monocelopsis, Archilopsis, and Archilina all contained only one species. Karling considered the generic characteristics as only species specific and synonymized these genera with $\boldsymbol{A r}$ chiloa De Beauchamp, 1910. The most important diagnostic features of this genus were a copulatory organ of the duplex type, the presence of a vagina, and the absence of an accessory prostatoid organ. As a consequence of the progressive increase of the number of species it has become possible to recognize similarities in the organization of the genital organs in species groups. Since these similarities differ from the basic condition (plesiomorphic characters) we consider these similarities as derived and therefore these species groups can be considered as monophyletic genera. These derived characters are the characters we have mentioned in the genus diagnoses (except for the genus Archilina) (see also Fig. 1). For the phylogenetic weight of these characters, see Martens \& Curini-Galletti, in press.

Ax (1959) created the new genus Archilina for $A$. endostyla, based on the presence of a stylet in the cirrus, despite the great similarity with the other genera of the complex. However, a stylet within the cirrus is also described for species belonging to the genera Duplominona, Duploperaclistus, and Archilopsis.

Some later described species and all new species here described show similarities with $A$. endostyla in the organization of the genital organs: a relatively short external vagina, presence of a prepenial bursa (which can be provided with glands and/or epithelium of the resorbiens type, at the place of connection with the female duct), and copulatory bulb (of the duplex type) rather compact with a relatively short cirrus. Besides these similarities, all species show an epidermis with insunk nuclei and the basic karyotype for the Monocelididae. On the basis of these characteristics we have brought these species together within the genus Archilina and rediagnosed the genus. These characters are also present in representatives of the Minoninae and other genera of the Monocelidinae, and therefore are plesiomorphic. The plesiomorphic organization of the genital organs is also present in the genera Monocelopsis and Mesoda within the Archiloa genus complex. Both genera have some derived differences as compared with Archilina. In Mesoda the nuclei are intra-epithelial, and in Monocelopsis the vitellaria lie behind the testes and are very few and the karyotype shows clear differences with the basic one found in species of the genus Archilina (see Curini-Galletti et al., 1989; Martens \& CuriniGalletti, in press).

The other genera (Archiloa, Inaloa, Archilopsis, and Tajikina) present clearly derived characters, morphological as well as karyological. For the genus Archilopsis we refer to Martens et al., 1989a. The genus $A$ rchiloa contains $A$. rivularis, $A$. petiti, and $A$. westbladi, and is based on the presence of an accessory cirrus in the copulatory bulb. Furthermore, in these species a vagina interna is present and no direct connection between the female duct 
and the prepenial bursa has been observed; they all have a very similar karyotype with $n=4$. Two other species, Inaloa cirrifera and a yet undescribed species of this genus also have four chromosomes in their haploid set, but these species together with $I$. scalopura have a vagina externa which has a clear connection with the female duct, and possess an extremely long cirrus. Therefore we have created for these species a new genus, Inaloa.

As a result of this systematic reassessment of the group, two species ("Archiloa" juliae Tajika, 1982 and "Archiloa" tajikai Ax \& Armonies, 1990) cannot be placed at present in any of the genera above. These species are only known from the North Pacific. The karyotype of $A$. juliae is unique (with only 2 chromosomes in the haploid set) and cannot be correlated with other species. The morphology of the genital organs is similar in these two species and is not in agreement with any of the genera recognized above. The main differences are: an internal vagina (cf. Archiloa) but a clear connection with the female duct is present, and the very numerous prostatoid glands do not lie in a separated prostatoid vesicle as is the case in the genera Inaloa and Archiloa. Therefore we have introduced for these species a new genus, Tajikina.

For the phylogenetic relationships between the genera mentioned above we refer to Martens \& Curini-Galletti, in press. From the discussion above it can be concluded that the re-defined genus $\mathrm{Archi}$ lina is a rather homogeneous group containing species with plesiomorphic characters. The possibility thus exists that the genus is non-monophyletic (see also Martens \& Curini-Galletti, in press). Within the genus, different species and species groups can be recognized on the basis of the number of testes, the detailed morphology of the vagina and prepenial bursa complex, and the morphology of the cirrus.

A first group that can be recognized is made up of $A$. vanderlandi, A. brachycirrus, A. selenifera, and $A$. biselenifera. They are all characterized by a reduction in the number of girdles of spines in the cirrus. Within the group, A. vanderlandi occupies an isolated position due to the number of testes, up to 20 , and a copulatory bulb nearly totally filled by the seminal vesicle, as the prostatic glands are very few. The cirrus has only two rows of spines mostly of the same size, around $9 \mu \mathrm{m}$ long. The species is only known from South Sulawesi. The other three species are all from the Mediterranean; they all have few testes, between 5 and 8; the copulatory bulb is very similar in all of them, with well-developed prostatic glands. In $A$. brachycirrus, the cirrus consists of two complete girdles of spines ( 3 to $6 \mu \mathrm{m}$ long), while in the other two species the girdles are more numerous (6 to 7) but they are not complete: $A$. selenifera has an interruption in the ventral side, and its spines range from 5 to $13 \mu \mathrm{m}$ in length; in $A$. biselenifera the girdles are interrupted dorsally as well as ventrally, and the spines range from 4 to $6 \mu \mathrm{m}$ in length. These three species probably from a separate lineage in the Mediterranean (cf. Fig. 11).

$\boldsymbol{A}$. papillosa and $\boldsymbol{A}$. caliban are clearly distinct from the others due to the presence of small spines, about $1-2 \mu \mathrm{m}$ in length. In $A$. caliban the cirrus is long (about $60 \mu \mathrm{m}$ ) and slender, while in A. papillo$s a$ it is only about $15 \mu \mathrm{m}$ long and partially triangular in shape (see Ax \& Ax, 1977, p. 16 (410), fig. 6).

$A$. duplaculeata is clearly distinct from the other species due to the presence of a group of very large spines, not belonging to the cirrus (probably atrial) (see Ax \& Armonies, 1990). It occupies an isolated position within the genus, and its systematic position is still unclear due to the lack of clear morphological information.

In general the remaining species are larger, with 20 or more testes, and are characterized by differences in size of the spines of the cirrus. Some of them have a stylet or stylet-like structures. $A$. endostyla is the only species known so far in the genus with a real stylet. $A$. subtilis and $A$. deceptoria both have few very long spines proximally (4-5, about $20 \mu \mathrm{m}$ long in $A$. subtilis; 4 , ranging from $27-30$ $\mu \mathrm{m}$ in length in $A$. deceptoria), which give the impression of an internal stylet; they can possibly function as a stylet. When the cirrus is everted, it is easy to observe that they are in reality separated spines. In $A$. subtilis there are about 7 regular girdles of spines within the cirrus, and the large spines are immediately followed by much smaller spines ( 5 to $8 \mu \mathrm{m}$ ) (see Karling et al., 1972, p. 252, fig. 7 and p. 258 , figs. 23 and 24 ). In this species the bursa is 


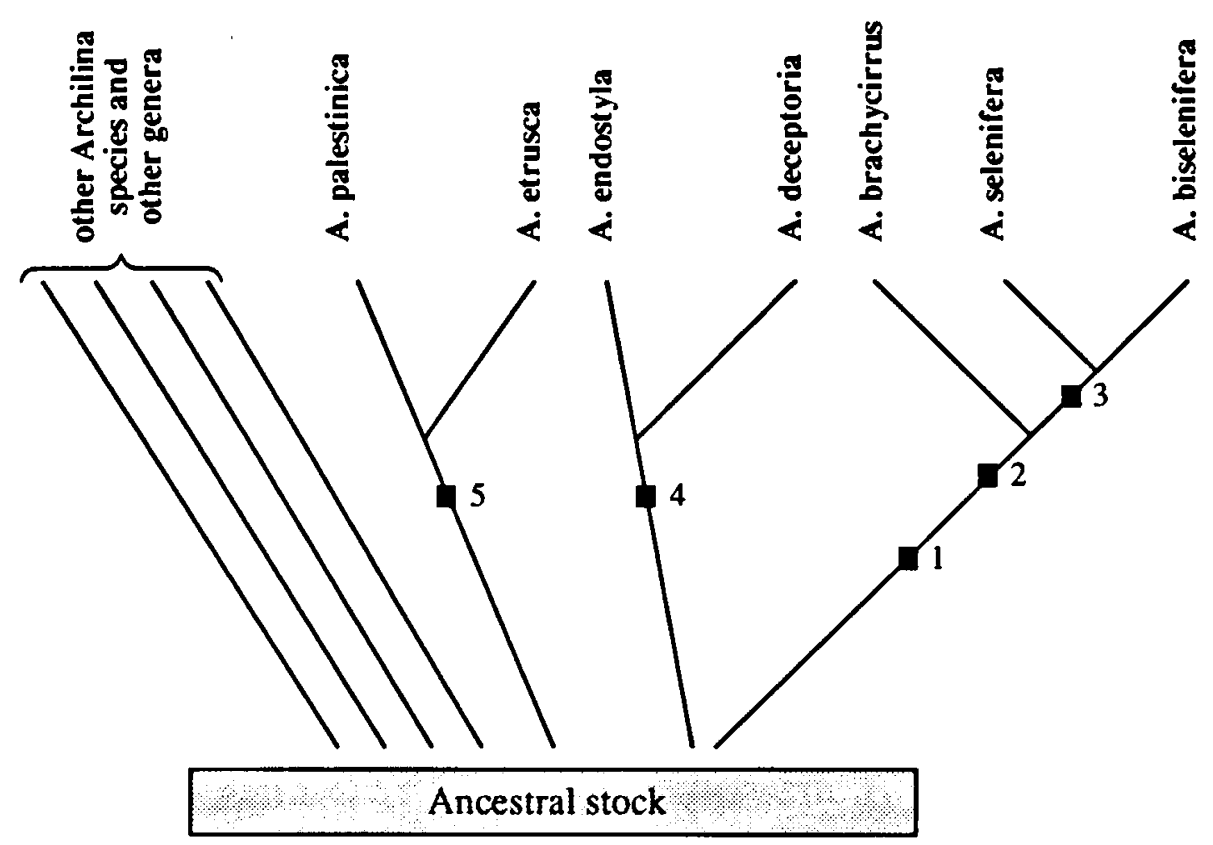

Fig. 11. Hypothesized relationships within the genus Archilina: 1, reduction of the number of testes; 2 , reduction of the number of girdles of spines in the cirrus; 3 , interruption of the ventral cirrus spines; 4 , complex vagina-bursa structure; 5 , sharp transition between large and small spines absent, most proximal spines being not the longest ones.

relatively simple (vaginal bursa), with a nonelongated roof; a genito-intestinal connection is present. In $A$. deceptoria there are 10-15 girdles of somewhat irregular spines, and the large spines are followed by spines becoming gradually smaller, ranging from 9 to about $1 \mu \mathrm{m}$ in length. Its bursal structure is complex, with the roof of the bursa elongated into a glandular bursa, which is followed by a bursa of the resorbiens type; no post-penial genito-intestinal connection has been seen. Furthermore, the two species come from different geographical regions: Hawaii Islands $(A$. subtilis) and W. Mediterranean ( $A$. deceptoria).

In $A$. palestinica and $A$. etrusca a sharp transition between large and small spines is absent and the most proximal spines are not the longest ones (Fig. 11). In living specimens there is never the impression that the larger spines form a stylet. In $\boldsymbol{A}$. etrusca the most distal spines are very small and these are followed by girdles with spines rapidly becoming much larger (up to $22 \mu \mathrm{m}$ in length); then, in the proximal half of the cirrus, the spines are smaller and more or less of the same size $(6-9 \mu \mathrm{m}$ long). In $A$. palestinica the proximal spines are the largest (16-22 $\mu \mathrm{m}$ long; the longest ones are not the most proximal ones); they become gradually smaller distally (to 3-6 $\mu \mathrm{m}$ long).

Among the Archilina species described so far (and numerous undescribed tropical species) some monophyletic groups of species can be recognized. They all seem to be more or less restricted to different geographical areas. However, and for the time being, we are unable to detect any synapomorphies between these groups. These groups (and the other genera of the complex; see Martens \& CuriniGalletti, in press) are probably the result of different evolutionary lines from ancestral stock of species with mainly plesiomorphic characters and a cosmopolitan distribution. This hypothesis includes that the monophyletic origin of this ancestral stock itself cannot be proved. Fig. 11 shows this hypothesis and the apomorphies for the monophyletic groups are given.

Within the genus Archilina, one separate evolutionary line is formed by $A$. brachycirrus - A. selenifera - $A$. biselenifera (for character analysis see 


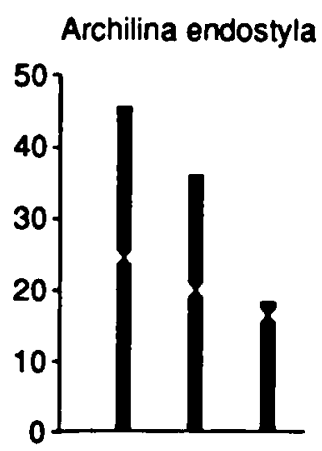

Archilina caliban (Pantelleria)

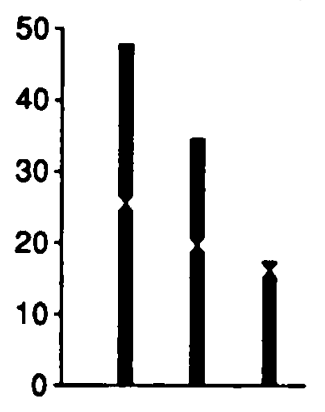

Archilina etrusca (Giglio)

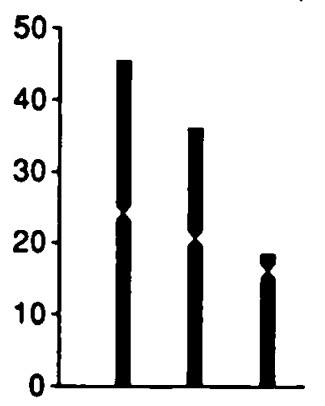

Archilina endostyla (Israel)

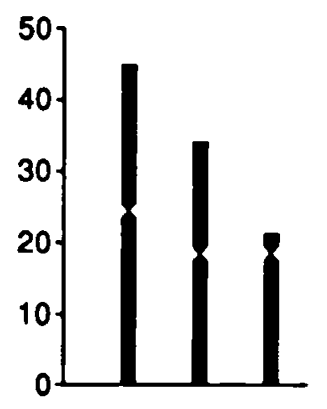

Archilina caliban (Israel)

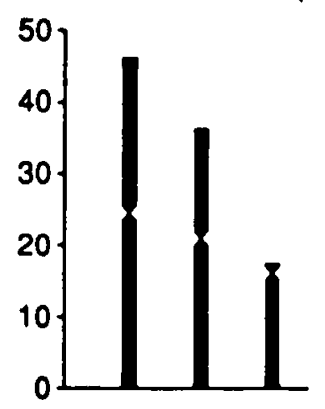

Archilina etrusca (Calvi)

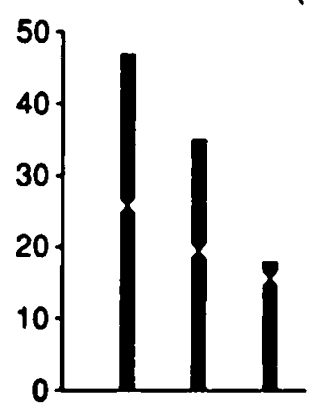

Archilina deceptoria (Calvi)

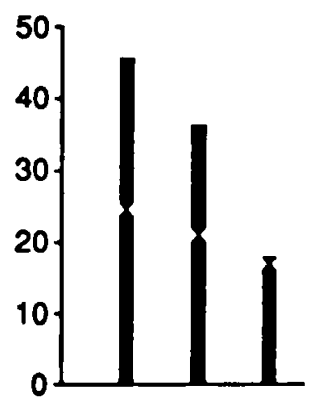

Archilina brachycirrus (Calvi)

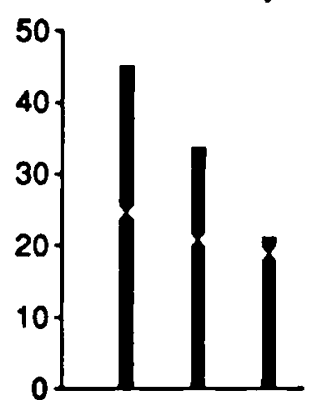

Archilina palestinica (Israel)

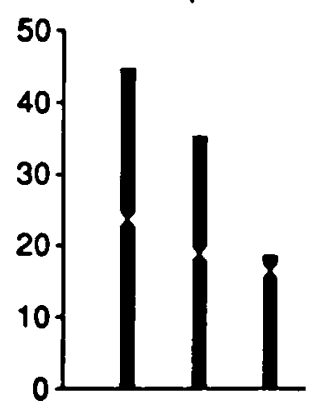

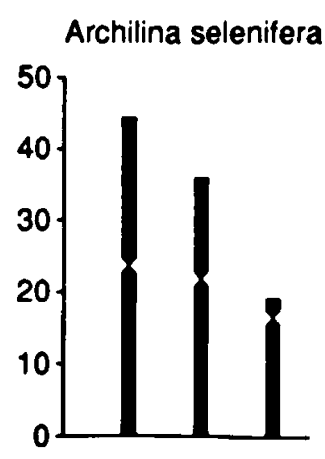

Archilina biselenifera (Punta Ala)

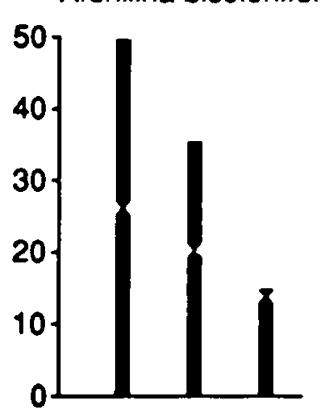

Fig. 12. Idiograms representing the haploid sets of Archilina species, based on data reported in species descriptions. 


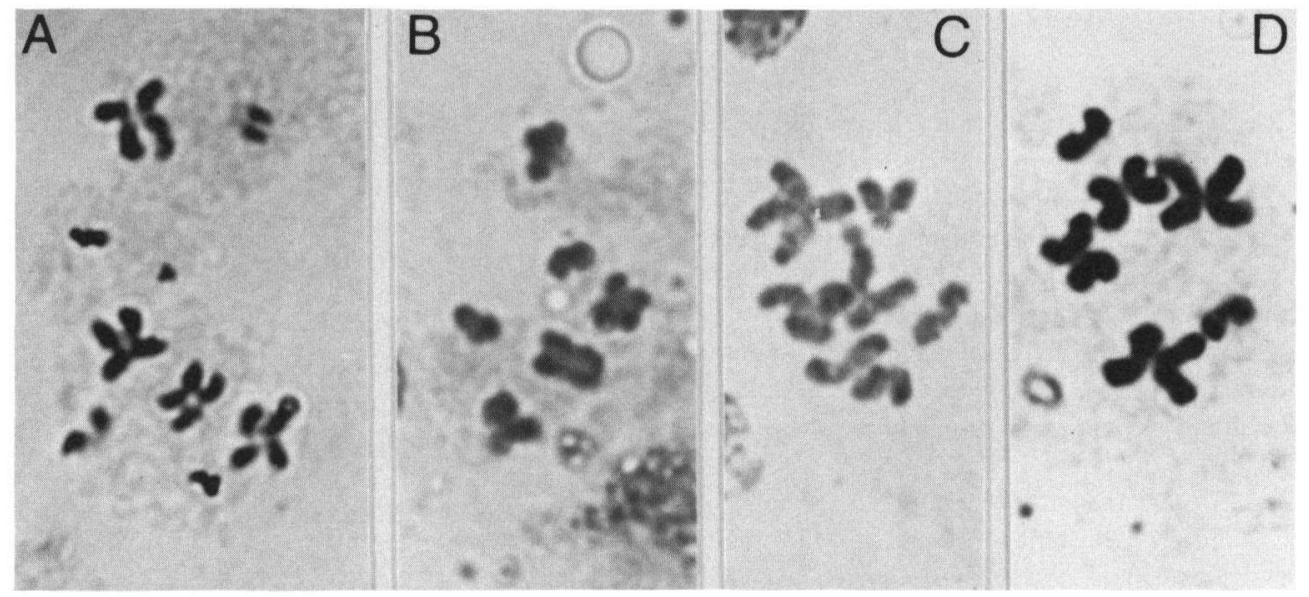

Fig. 13. Plates of spermatogonial mitoses: A, Archilina palestinica; B, A. endostyla (from Israel); C, A. selenifera; D, A. caliban.

above). A. selenifera and $A$. biselenifera are probably geographically vicariant, from the eastern and western Mediterranean, respectively. A. vanderlandi from South Sulawesi, though similar to $A$. brachycirrus as far as the cirrus is concerned, is nonetheless distinct for other features of the male genital system, and likely to represent a member of an independent, Indo-Pacific line.

Another group is represented by the species with stylet or stylet-like structures. Among them, A. endostyla and $A$. deceptoria have a complex vaginabursa structure, which is dorsally elongated, with the most dorsal region differentiated as a resorbiens bursa (Fig. 11). This is suggestive of a sister-species relationship among them, with the morphological stylet of $\boldsymbol{A}$. endostyla being homologous with the functional stylet of $A$. deceptoria. Both species are from the Mediterranean, and are ecologically separated: $A$. deceptoria is the most common Archilina species in subtidal areas in the western Mediterranean; $A$. endostyla, with the exception of the Israelian population, is confined to brackish areas, where it can be among the most abundant of meiofaunal organisms. Though the cirrus of $A$. deceptoria is most similar to that of $\boldsymbol{A}$. subtilis, the latter species, among other things, has a simple bursa, lacking the resorbiens portion; it is likely to represent an independent, Indo-Pacific line of evolution of a functional stylet.

A further possible sister-species relationship can be postulated for $A$. etrusca and $A$. palestinica: they share similarities in the cirrus structure (see above) and they both have a rather simple, ovoid bursa, without an evident resorbiens portion. Here again the species are probably geographically vicariant: $A$. etrusca is common in the lower intertidal to a few decimetres deep in protected areas in the western Mediterranean, and able to withstand moderate brackish conditions. A. palestinica has been found abundantly in a comparable habitat in Israel.

The karyotype of eight of the twelve Archilina species is known (Fig. 12). They all have $n=3$, with one large metacentric, one medium-sized metacentric, and one small heterobrachial chromosome. The fundamental number is 5 in all species and their haploid genome length ranges from 6.4 to $11.9 \mu \mathrm{m}$. Therefore, they all show the plesiomorphic condition for the Monocelididae (see Curini-Galletti et al., 1989).

\section{Acknowledgements}

We thank for hospitality and for providing working facilities: Prof. Dr. E. Nevo (Director) and members of the Institute of Evolution (University of Haifa, Israel); Prof. Dr. T. Elefteriou and Dr. E. Roidou (Heraklion, Crete, Greece); Dr. D. Bay, Director of STARESO (Calvi, France); Prof. Dr. F. Boero and Dr. A. Giangrande (University of Lecce, Italy). Dr. Lester Cannon (Brisbane, Australia) and Dr. Alain De Vocht are thanked for critically reading the manuscript, and Magda levens and Mark Withofs for technical assistance. 


\section{References}

Ax, P., 1959. Zur Systematik, Ökologie und Tiergeographie der Turbellarienfauna in den ponto-kaspischen Brackwassermeeren. Zool. Jb., (Syst.) 87 (1/2): 43-184.

Ax, P. \& W. Armonies, 1987. Amphiatlantic identities in the composition of the boreal brackish water community of Plathelminthes. Microfauna marina, 3: 7-80.

Ax, P. \& W. Armonies, 1990. Brackish water Plathelminthes from Alaska as evidence for the existence of a boreal brackish water community with circumpolar distribution. Microfauna marina, 6: 7-109.

Ax, P. \& R. Ax, 1977. Interstitielle Fauna von Galapagos XIX. Monocelididae (Turbellaria, Proseriata). Mikrofauna Meeresbodens, 64: 1-44.

Curini-Galletti, M., L. Galleni, P.M. Martens, I. Puccinelli \& E. Schockaert, 1984. Karyological observations on Turbellaria Proseriata. Boll. Zool. (Suppl.), 51: 35.

Curini-Galletti, M.\& P.M. Martens, 1990. Karyological and ecological evolution of the Monocelididae (Platyhelminthes, Proseriata). Marine Ecology P.S.Z.N., 11 (3): 255-261.

Curini-Galletti, M., P.M. Martens \& I. Puccinelli, 1985. Karyological observations on Monocelididae (Turbellaria, Proseriata): karyometrical analysis of four species pertaining to the subfamily Minoninae. Cariologia, 38 (1): 67-75.

Curini-Galletti, M., I. Puccinelli \& P.M. Martens, 1989. Karyometrical analysis of ten species of the subfamily Monocelidinae (Proseriata, Platyhelminthes) with remarks on the karyological evolution of the Monocelididae. Genetica, 78: 169178.

Karling, T.G., 1966. Marine Turbellaria from the Pacific coast of North America IV. Coelogynoporidae and Monocelididae. Ark. Zool., 18: 493-528.

Karling, T.G., 1978. Anatomy and systematics of marine Turbellaria from Bermuda. Zoologica Scr., 7: 225-248.

Karling, T.G., V. Mack-Fira \& J. Dörjes, 1972. First report on marine microturbellaria from Hawaii. Zoologica Scr., 1: 251269.

Levan, A., K. Fredga \& A.A. Sandberg, 1964. Nomenclature for centrometric position on chromosomes. Hereditas, 52: 201220.

Martens, E.E., 1984. Ultrastructure of the spines in the copulatory organ of some Monocelididae (Turbellaria, Proseriata). Zoomorphology, 104:261-265.

Martens, E.E., 1986. Comparative ultrastructure of copulatory organs having a stylet in the Proseriata (Turbellaria). Hydrobiologia, 132: 165-173.

Martens, P.M., 1983. Three new species of Minoninae (Turbellaria, Proseriata, Monocelididae) from the North Sea, with remarks on the taxonomy of the subfamily. Zoologica Scr., 12 (3): 153-160.

Martens, P.M., 1984. Comparison of three different extraction methods for Turbellaria. Mar. Ecol. Progr. Ser., 14: 229-234.

Martens, P.M. \& M.C. Curini-Galletti, 1989. Platyhelminthes from South-Sulawesi (Indonesia) part 1: Monocelididae and Archimonocelididae (Proseriata). Trop. Zool., 2: 175-205.

Martens, P.M. \& M.C. Curini-Galletti, 1993. Taxonomy and phylogeny of the Archimonocelididae Meixner, 1938 (Platyhelminthes, Proseriata). Bijdr. Dierk. 63 (2): 65-102.

Martens, P.M. \& M.C. Curini-Galletti, in press. Phylogenetical relationships within the Archiloa genus complex. Hydrobiologia.

Martens, P.M., M.C. Curini-Galletti \& I. Puccinelli, 1989a. On the morphology and karyology of the genus Archilopsis (Meixner) (Platyhelminthes, Proseriata). Hydrobiologia, 175: 237-256.

Martens, P.M., M.C. Curini-Galletti \& P. Van Oostveldt, 1989 b. Polyploidy in Proseriata (Platyhelminthes) and its phylogenetical implications. Evolution, 43 (4): 900-907.

Martens, P.M. \& E.R. Schockaert, 1988. Phylogeny of the digonoporid Proseriata. Progr. Zool., 36: 399-403.

Matthey, R., 1949. Les chromosomes des Vertébrés: 1-344 (Rouge, Lausanne).

Sopott, B., 1972. Systematik und Ökologie von Proseriaten (Turbellaria) der deutschen Nordseeküste. Mikrofauna Meeresbodens, 13: 1-72.

Received: 1 December 1993

Revised: 9 March 1994 